\title{
RANGE EXTENSION FOR RICCIA NIPPONICA AND COMMENTS ON THE R. CRYSTALLINA COMPLEX (RICCIACEAE, HEPATICAE)
}

\author{
Eugene A. Borovichev \& Vadim A. Bakalin
}

\begin{abstract}
For Riccia nipponica S. Hatt., previously regarded as a Japanese endemic, the paper gives the first records from the southern flank of the Russian Far East and Guizhou Province of China. These records considerably enlarge its known distribution area. New data on its morphological variability, ecology and distribution patterns are summarized and analyzed based on study of available material from East Asia. A morphological description and figures are given, with a key in table form for it and related taxa. Although closely related to the sub-cosmopolitan $R$. crystallina L., $R$. nipponica merits species rank.
\end{abstract}

Key words: distribution, ecology, endemic species, hepatics, phytogeography, Riccia, Ricciaceae

Eugene A. Borovichev, Institute of Industrial Ecology Problems of the North, Kola Science Center of RAS, Apatity, Murmansk Province, 184209, Russia, and Polar-Alpine Botanical Garden-Institute, Kola Science Center of RAS, Kirovsk, Murmansk Province, 184256, Russia; e-mail: borovichyok@mail.ru

Vadim A. Bakalin, Botanical Garden-Institute FEB RAS, Makovskogo Street, 142, Vladivostok, 690024, Russia, and Institute of Biology and Soil Science FEB RAS, Stoletiya Vladivostoka Avenue, 159, Vladivostok, 690022, Russia; e-mail: v_bak@list.ru

\section{INTRODUCTION}

The genus Riccia L. is the largest and the most taxonomically difficult genus of marchantioid hepatics. It numbers at least 150 species worldwide (Bischler 1998), most diverse in areas of temperate to subtropical Mediterranean and continental climate. East Asia is one of the diversity centers of the genus; the taxonomic status and variability range of many species occurring there remain unclear. The genus has never been revised for Asia, though there are data for other regions such as the Mediterranean (Jovet-Ast 1986), Nordic countries (Damsholt 2002), Europe (Müller 1954), the British Isles (Paton 1999), India (Pande \& Udar 1957, 1958, 1959; Meijer 1958; Srivastava 1964; Bapna \& Kachroo 2000), Southern Africa (Perold 1999), North America (Schuster 1992) and some regions of South America (Hässel de Menéndez 1963; Jovet-Ast 1991，1993，2005; Gradstein \& Costa 2003).

The eastern margin of East Asia has numerous endemic (at least so treated) taxa adapted to rather humid climate. Most of them are foliose genera, with a few exceptions for marchantioid taxa. Three species of Riccia described from Japan belong to the latter group and are still regarded as Japanese endemics - Riccia miyakeana Schiffn. (Schiffner 1899), R. nipponica S. Hatt. (Shimizu \& Hattori 1953 ) and $R$. pubescens S. Hatt. (Hattori 1943). However, there are no factors that might potentially limit their distribution outside of Japan.

In the course of a revision of Riccia for the Russian Far East and adjacent areas, we found specimens of the $R$. crystallina complex both from the Russian Far East and from Guizhou Province, China. Both specimens belong to $R$. nipponica, and this finding considerably enlarges the range of the species.

Riccia nipponica was described in 1953 by S. Hattori from Obi in Miyazaki Prefecture, Japan (Shimizu \& Hattori 1953), characterized by (1) growing as large rosettes or hemirosettes, (2) the upper surface of the thallus bluish in younger parts and grayish green or yellowish in older parts, (3) the upper surface not or slightly lacunose towards the apex and sparsely lacunose in older ones, (4) lobes 2.5-5.0 mm wide, (5) the 

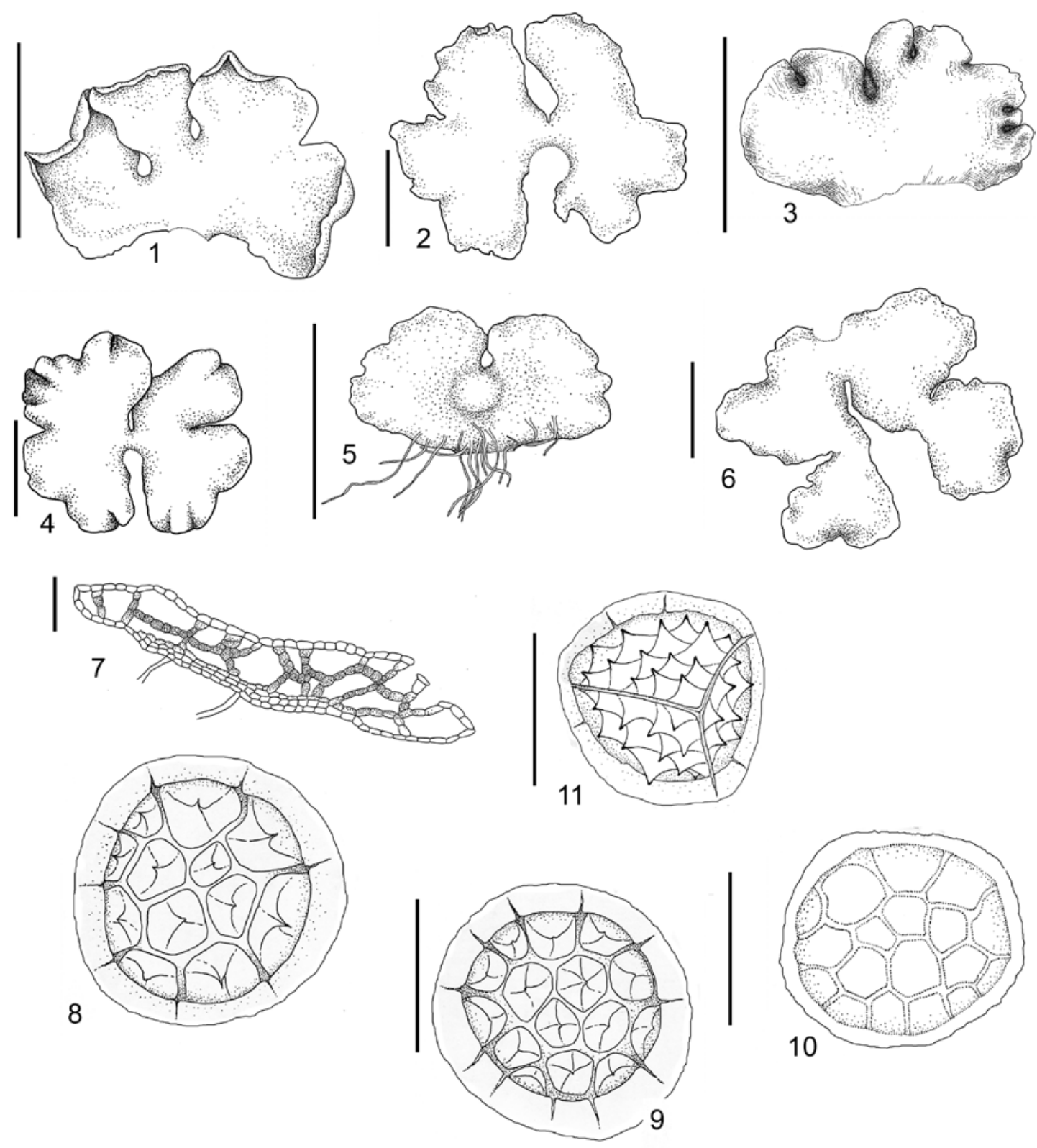

Fig. 1. Riccia nipponica S. Hatt. 1-4 \& 6-habit of plant, dorsal view, 5-habit of plant, ventral view, 7 - cross section of thallus, 8-10 - distal face of spores, 11 - proximal face of spores (1, 2, 5-7, 9-11 from Khabarovsk Territory, 16 Sept. 1986, Shelestova, KPABG; 3, 4, 8 from Guizhou Province, 19 Nov. 2013, Bakalin, VBGI). Scale bars: $1-6=3 \mathrm{~mm} ; 7=600 \mu \mathrm{m} ; 8-11=45 \mu \mathrm{m}$.

thallus 4-5 times wider than high in cross section, (6) the upper surface of older thallus segments and dried plants with a scruffy appearance because of disintegration of epidermal cells, (7) minute ventral scales, (8) spores (60-)70-80 $\mu \mathrm{m}$ in diameter, with large complete alveoli on the distal face, and (9) - finely dentate spore tetrahedral wings $8-12 \mu \mathrm{m}$ wide. 
Most of the listed characters $(1,2,3,5,6,7,8)$ are the same in $R$. crystallina L. (Jovet-Ast 1964), as it is most closely related to $R$. nipponica, but the latter differs from $R$. crystallina in having $(i)$ lobes 2.5-5.0 mm wide (vs. 2.0-4.0 mm wide in R. crystallina), (ii) the spore distal surface with $4(-5)$ large complete alveoli across the spore diameter (vs. 5-10 complete alveoli), (iii) the wing (4-)6$8(-12) \mu \mathrm{m}$ wide (vs. 3-6 $\mu \mathrm{m}$ wide), and (iv) the spine usually present in the center of alveoli (vs. spine absent). In both the Chinese and Russian specimens these differentiating features are more or less stable and may be used to confirm that $R$. nipponica merits species rank. As the present records are the first reports of the species outside of Japan, and in order to draw attention to this poorly known species which no doubt should be found in other areas of East Asia, here we describe its morphology from specimens examined, and indicate the differences from closely related taxa.

Riccia nipponica S. Hatt.

Figs $1 \& 2$

J. Hattori Bot. Lab. 9: 38. 1953.

Plants crystalline; as discrete thalli, forming rosettes or hemirosettes. Thalli medium-sized, 2.5-5.0 mm wide, 5-7 mm long; 2-4-times furcate; lobes short, wide, obcordate; upper surface light green to somewhat bluish green, in older parts becoming whitish or yellowish; not or slightly lacunose towards the apex and sparsely lacunose in older parts; apex thick, rounded to shortly emarginate; median furrow distinct at apex, shallow; thallus margins raised, not incurved, rounded, obtuse. Dorsal epidermis cells almost globular, shiny, 45-56 $\mu \mathrm{m}$ wide; thin-walled. Cross section elliptical, not furrowed; 3-5 times wider than thick; assimilation tissue high, compact; 400-550(-600) $\mu \mathrm{m}$ thick, occupying 2/3-3/4 of thallus thickness in the middle; air chambers narrow near apex and wider toward base, in 1-2 layers in the middle. Ventral tissue parenchymatous, consisting of thin-walled cells; occupying $1 / 4-1 / 3$ of thallus thickness in the middle. Ventral surface green; thallus midrib fleshy, 600-800 $\mu \mathrm{m}$ thick in cross section; relatively well-defined. Rhizoids smooth and pegged, hyaline, covering ventral surface of midrib of

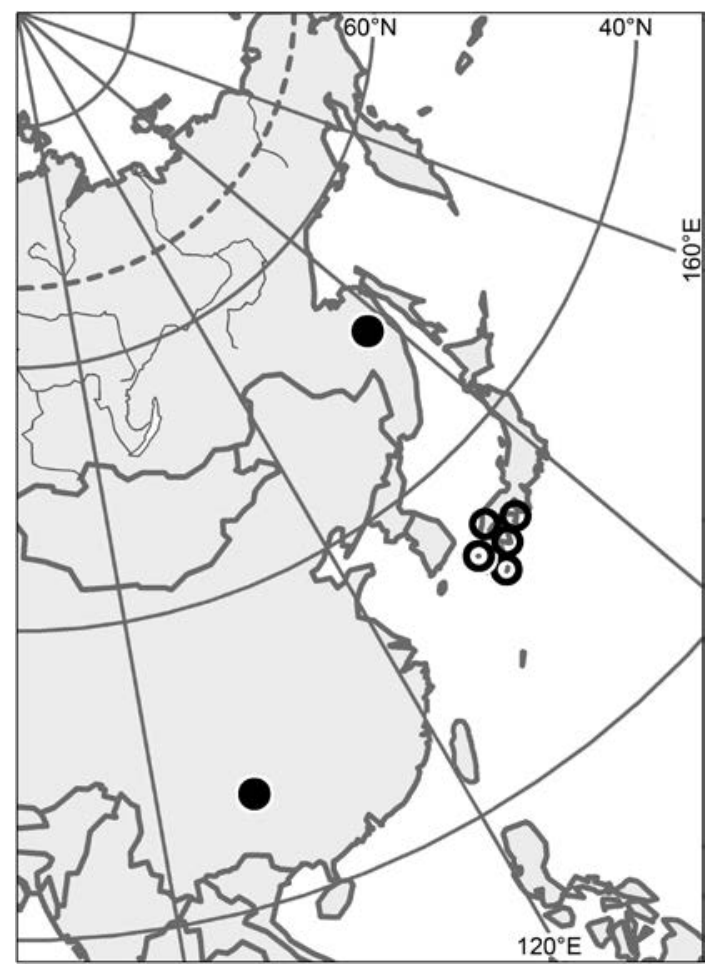

Fig. 2. Distribution of Riccia nipponica S. Hatt. $\mathbf{O}$ - previously known localities; - localities discovered during our study.

thallus. Ventral scales developed mostly near apex; inconspicuous hyaline, minute. Monoicous. Antheridia in two lateral rows along dorsal part of thallus, with necks hyaline, up to $150-180 \mu \mathrm{m}$ long. Archegonia along thallus middle, with necks purple-brown, up to $180-210 \mu \mathrm{m}$ long. Sporangia numerous, dorsal, slightly protruding ventrally. Spores $55-70(-78) \mu \mathrm{m}$ in diameter; light to dark yellowish or brownish; distal face alveolate, with laminae forming 4-5(-6) complete, round alveoli across the face, $8-10(-12) \mu \mathrm{m}$ in diameter; lamellae thin and low, usually with spine in center of alveoli; proximal face similar to distal surface or less regularly reticulate, with distinct trilete scar; wings (4-)6-8(-12) $\mu \mathrm{m}$ wide; wing margin crenulate to spinulose, sometimes erose.

SPECIMENS EXAMINED (newly reported areas asterisked): "RUSSIA, KhabarovsK Territory, Komsomolsk State Nature Reserve, Amur River Upland, mouth of Gorin River, Bichi Island $c a 70 \mathrm{~km}$ downstream of 
Table 1. Comparison of Riccia L. species morphologically similar to R. nipponica S. Hatt.

\begin{tabular}{|c|c|c|c|}
\hline Character & R. cavernosa Hoffm. & R. crystallina $\mathrm{L}$. & R. nipponica $\mathrm{S}$. Hatt. \\
\hline Growth form & $\begin{array}{l}\text { narrow discrete thalli, ro- } \\
\text { settes or hemirosettes }\end{array}$ & $\begin{array}{l}\text { discrete thalli, rosettes or } \\
\text { hemirosettes }\end{array}$ & $\begin{array}{l}\text { discrete thalli, rosettes or } \\
\text { hemirosettes }\end{array}$ \\
\hline Color of thallus upper surface & $\begin{array}{l}\text { green, yellowish, or light- to } \\
\text { grayish green, often with red- } \\
\text { dish secondary pigmentation }\end{array}$ & $\begin{array}{l}\text { bluish to grayish but turning } \\
\text { whitish upon drying in the } \\
\text { field }\end{array}$ & $\begin{array}{l}\text { light green to somewhat bluish } \\
\text { green, in older parts becoming } \\
\text { whitish or yellowish }\end{array}$ \\
\hline Thallus segment width, $\mathrm{mm}$ & $1.0-2.0(-2.7)$ & $1.5-2.5(-4.0)$ & $2.5-5.0$ \\
\hline Dorsal epidermis & $\begin{array}{l}\text { slightly to very distinctly } \\
\text { lacunose or alveolate }\end{array}$ & $\begin{array}{l}\text { not or very indistinctly perfo- } \\
\text { rated towards apex and often } \\
\text { less conspicuously lacunose } \\
\text { in older part of thallus }\end{array}$ & $\begin{array}{l}\text { not or slightly lacunose } \\
\text { towards apex and sparsely } \\
\text { lacunose in older parts }\end{array}$ \\
\hline Texture of thallus & spongy & somewhat compact & somewhat compact \\
\hline $\begin{array}{l}\text { Thallus cross section, width/ } \\
\text { thickness ratio }\end{array}$ & $1.5-2.5(-4.0)$ & $2.5-4.0$ & $3-5$ \\
\hline Ventral scales & lacking & $\begin{array}{l}\text { narrowly lunate, small, } \\
\text { ephemeral }\end{array}$ & minute \\
\hline Texture of thallus & not crystalline & glistening and crystalline & glistening and crystalline \\
\hline Diameter of spores, $\mu \mathrm{m}$ & $65-95$ & $60-86$ & $55-70(-78)$ \\
\hline Spore distal face & $\begin{array}{l}\text { lamellae irregular, short and } \\
\text { low toward margin, often } \\
\text { forming incomplete alveoli }\end{array}$ & $\begin{array}{l}\text { with } 7-10 \text { complete small } \\
\text { alveoli across spore diameter }\end{array}$ & $\begin{array}{l}\text { with 4-5 large, complete } \\
\text { alveoli across spore diameter }\end{array}$ \\
\hline Tubercles or spines & $\begin{array}{l}\text { without tubercles or spines at } \\
\text { the angles }\end{array}$ & $\begin{array}{l}\text { with tubercles or spines at } \\
\text { the angles }\end{array}$ & $\begin{array}{l}\text { with spine in center of al- } \\
\text { veoli, but not in angles }\end{array}$ \\
\hline Width of spores wings, $\mu \mathrm{m}$ & $3-8$ & $3-4(-6)$ & $(4-) 6-8(-12)$ \\
\hline Distribution & Subcosmopolite & Subcosmopolite & East Asian \\
\hline
\end{tabular}

Seimchan settlement, $50^{\circ} 45^{\prime} \mathrm{N}, 137^{\circ} 40^{\prime} \mathrm{E}$, sandy-loam bank, mixed with $R$. frostii, with sporophytes, 16 Sept. 1986, Shelestova, s.n. (VBGI; as R. huebeneriana); ${ }^{*}$ CHINA, Guizhou Province, Kaijang County, Xiang Zhi Stream, $26^{\circ} 46^{\prime} 59,5^{\prime \prime} \mathrm{N}, 106^{\circ} 54^{\prime} 44,5^{\prime \prime} \mathrm{E}$, agricultural land in countryside, clay on rice field margin, with sporophytes, 19 Nov. 2013, V.A. Bakalin \#China521-13 (VBGI; KPABG; as $R$. cavernosa); JAPAN, Obi-cho, Minaminaka-gun, 7 March 1950, S. Hattori \#16015 (TNS); ibidem, on soil, 5 Feb. 1953, S. Hattori \& D. Shimizu \#51535 (NICH, holotype of R. nipponica); FuKuoka Prefecture, 5 Jan. 1958, Yu. Kuwahara (LE, KPABG, VBGI - Hepaticae Japonicae Exsiccatae, Ser. 1: 22); Ibaragi-ken, Joshu-shi, Higashi-Mati, Fukuoka, near Toshuko Bridge, 13 Dec. 2007, Q. Latiff (HIRO 247230; as R. cavernosa); Honshu, Hiroshima-ken, Higashi-hiroshima-shi, Kagamiyama, on soil, 19 April 2001, M. Itouga \#3826 (HIRO; as Riccia); Saitamaken, Saitama-shi, Midori-ku, Minuma, on moist soil in nursery garden, 8 Nov. 2007, M. Itouga \#4067 (HIRO; as Riccia); SнгкокU, Kochi-ken, Nagaoka-gun, Motoymacho, Sukefuji, on moist soil in rice field, 24 Jan. 2008, H. Deguchi \#37896 (HIRO 247484; as Riccia).
DifFERENTIATION. Riccia nipponica is most closely related to $R$. crystallina and $R$. cavernosa. The main differences are given in Table 1. Confusion with other taxa seems hardly possible. As is evident from the table, some features intergrade from one to another species, which may reflect the recent divergence of these taxa.

VARIATION. The studied specimens vary in spore size, number of alveoli across spore diameter, and width of spore wing. The spores from the Khabarovsk Territory specimen are smaller [(53-)55-65 $\mu \mathrm{m}$ in diameter] than in the Japanese and Chinese specimens $(65-78 \mu \mathrm{m})$. Typically, as described by Shimizu and Hattori (1953), the spore distal face has 4 large complete alveoli across spore diameter, but in our studied specimens we found $4(-5)$ large complete alveoli in Japanese plants (Hattori, 7 March 1950), 4-5(-6) complete alveoli in plants from Khabarovsk Territory, and 4 large complete alveoli in Chinese plants. Spore wing width varies even within one 
sporangium from 4-6 $\mu \mathrm{m}$ to $8-10(-12) \mu \mathrm{m}$. Unlike the specimens from the Russian Far East and Japan, the Chinese specimens have a noticeably lacunose dorsal surface resembling $R$. cavernosa in appearance, but other features like spore size and ornamentation coincided with those of the plants from Japan described by Shimizu and Hattori (1953). The likely explanation of these discrepancies is wider morphological variability than was suggested before (Shimizu \& Hattori 1953).

ECOLOGY. The habitat of Riccia nipponica in Japan is fine earth in subtropical broadleaved, mostly evergreen forest with high annual precipitation in Myazaki and Fukuoka Prefectures, rather similar to the conditions prevailing where the species was collected in Guizhou Province, China. In contrast, its locality in the Russian Far East belongs to the so-called 'Ussuri taiga' zone (mixed coniferous-broadleaved forest in the contact zone of temperate and boreal vegetation), where it inhabited a sandy-loamy stream bank together with $R$. frostii Austin. Probably the latter is a relict locality and reflects the area's ancient connections with the warm-temperate plant cover of East Asia.

Distribution. Earlier R. nipponica was treated as a Japanese endemic; there it is more or less common on Honshu, Shikoku ans Kyushu Islands (Yamada \& Iwatsuki 2006; Higuchi 2011; our data). Both of our records are from areas far from the nearest known locations in Japan: over $2000 \mathrm{~km}$ north to Khabarovsk Territory and ca $2300 \mathrm{~km}$ southwest to Guizhou Province. In view of the great distance between these currently known localities, we expect $R$. nipponica to be found in many other areas in East Asia in the course of future investigations.

ACKNOWLEDGEMENTS. We are greatly indebted to the curators of NICH (Dr. Masami Mitzutani) HIRO (Prof. Tomio Yamaguchi) and TNS (Dr. Masanobu Higuchi) for specimen loans, Mr. Matvey Bakalin for preparing the figures, Mr. Anatolij Savchenko for preparing the distribution map, and the anonymous reviewer for helpful remarks and suggestions on the manuscript. This work was supported in part by the Russian Foundation for Basic Research (grants no. 13-04-00775, 15-04-03479, 15-34-20101) and the President's Program for Support of PhD Research (MK-2926.2015.4).

\section{REFERENCES}

Bapna K. R. \& Kachroo P. 2000. Hepaticology in India. 2. Himanshu Publications, Udaipur, New Delhi.

BisCHLER H. 1998. Systematics and evolution of the genera of the Marchantiales. Bryophyt. Biblioth. 51: 1-201.

DAmsholt K. 2002. Illustrated Flora of Nordic Liverworts and Hornworts. Nordic Bryological Society, Lund.

Gradstein S. R. \& Costa D. P. 2003. The Hepaticae and Anthocerotae of Brazil. Mem. New York Bot. Gard. 87: 1-318.

HäSSEl de MenÉndez G. 1963. Estudio de las Anthocerotales y Marchantiales de la Argentina. Opera Lilloana 7: 1-297.

Hattori S. 1943. Ricciaceae nipponicae. National Science Museum 14: 138-143.

Higuchi M. 2011. Endemic Species of Bryophytes in Japan. Bull. Natl. Mus. Nat. Sci., Ser. B. 37(3): 117-126.

Jovet-Ast S. 1964. Riccia crystallina L. emend. Raddi et Riccia cavernosa Hoffm., emend. Raddi (Note Preliminaire). Rev. Bryol. Lichénol. 33: 459-483.

Jovet-Ast S. 1986. La Riccia de la Région Méditerraniéene. Cryptogamie, Bryologique et Lichénologique 7: 283-431.

Jovet-Ast S. 1991. Riccia (Hépatiques, Marchantiales) d'Amérique Latine. Taxons du Sous-Genre Riccia. Cryptog. Bryol. Lichénol. 12(3): 189-370.

Jovet-Ast S. 1993. Riccia (Hépatiques, Marchantiales) d'Amérique Latine. Taxon des sous-genres Thallocarpus, Leptoriccia, Ricciella. Cryptog. Bryol. Lichénol. 14(3): 219-301.

Jovet-Ast S. 2005. Riccia. In: H. Bischler-Causse, S. R. Gradstein, S. Jovet-Ast, D. G. Long \& N. Salazar Allen, Marchantiidae. Flora Neotropica 97: 25-123. New York Botanical Garden Press, New York.

MeIJER W. 1958. Notes on species of Riccia from the Malaysian Region. J. Hattori Bot. Lab. 20: 107-118.

MüLLER K. 1954. Die Lebermoose Europas. In: Rabenhorst's Kryptogamenflora von Deutschland, Österreich und der Schweiz. 3. Auflage. 6(1): 1-756. Akademische Verlagsgesellschaft Geest \& Portig K.-G., Leipzig.

Pande S. K. \& Udar R. 1957. Genus Riccia in India I. A reinvestigation of the taxonomic status of the Indian species of Riccia. J. Indian Bot. Soc. 36: 564-579.

Pande S. K. \& Udar R. 1958. Genus Riccia in India II. Species of Riccia from India with description of new species and notes on synonyms of some recently described ones. Proc. Natl. Inst. Sci. India, B 24: 79-88.

Pande S. K. \& Udar R. 1959. Genus Riccia in India III. Species of Riccia from the East Himalayan territory with description of a new species, $R$. attenuata Pande sp. nov. Proc. Natl. Inst. Sci. India, B 25: 90-100.

PAton J. A. 1999. The liverwort flora of the British Isles. Harley Books, Colchester. 
Perold S. M. 1999. Flora of Southern Africa. Hepatophyta. Part 1: Marchantiopsida. Fascicle 1: Marchantiidae In: O. A. Leistner (ed.), Flora of Southern Africa. Hepatophyta, pp. 1-252. National Botanical Institute, Pretoria.

SCHIFFner V. 1899. Ueber einige Hepaticae aus Japan. Oesterr. Bot. Z. 49: 385-395.

SChuster R. M. 1992. The Hepaticae and Anthocerotae of North America. 6. Field Museum of Natural History, Chicago.
Shimizu D. \& Hattori S. 1953. Marchantiales of Japan, I. J. Hattori Bot. Lab. 9: 32-44.

Srivastava K. P. 1964. Bryophytes of India I. Ricciaceae. Bull. Lucknow Natl. Bot. Gard. 104: 1-103.

YAMADA K. \& IwATSUKi Z. 2006. Catalog of the hepatics of Japan. J. Hattori Bot. Lab. 99: 1-106.

Received 4 April 2015 